
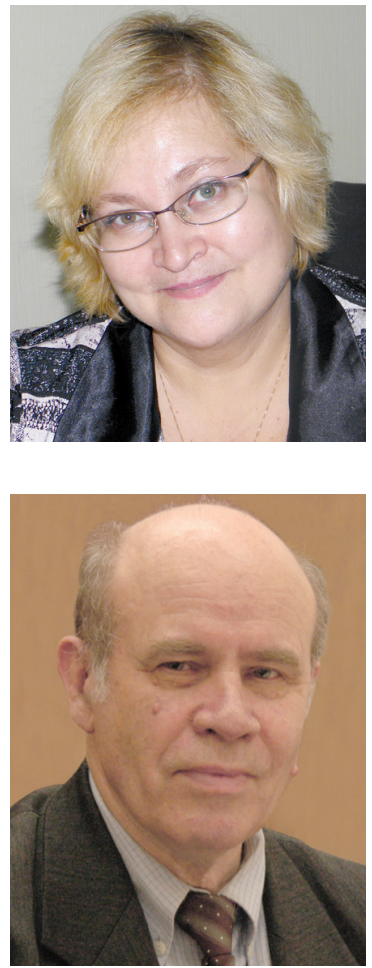

\section{Демина Ирина Николаевна}

доктор экономических наук, профессор, декан факультета журналистики, Байкальский государственный университет, 664003, Российская Федерация, г. Иркутск, ул. Ленина, 11, e-mail: demina-in@bgu.ru

\section{Irina N. Demina}

DPhil. in Economics, Professor, Head of the Faculty of Journalism, Baikal State University, 11 Lenin St., 664003, Irkutsk, Russian Federation, e-mail: demina-in@bgu.ru

\section{Шкондин Михаил Васильевич}

доктор филологических наук, профессор, фракультет журналистики, Московский государственный университет имени М. В. Ломоносова, 125009, Российская Федерация, г. Москва, ул. Моховая, 9, e-mail: skond@mail.ru

\section{Mikhail V. Shkondin}

DPhil. in Philology, Professor, Lomonosov Moscow State University, 9 Mokhovaya St., 125009, Moscow, Russian Federation, e-mail: skond@mail.ru

\title{
ЖУРНАЛИСТИКА КАК ФАКТОР ПУБЛИЧНОСТИ: СИСТЕМНЫЕ АСПЕКТЫ
}

\footnotetext{
Аннотация. В условиях становления нового этапа цивилизационного процесса обостряется противоречие между общественными потребностями в публичности социальной деятельности и возможностями их удовлетворения средствами массовой информации. Системный анализ данной проблемы говорит о необходимости существенной актуализации таких интегративных качеств и свойств медиасистемы, как ее функциональная, структурная, коммуникативная и организационная целостности.

Не умаляя значения дальнейшей актуализации традиционных функций журналистики, в статье идет речь о необходимости исследования ее функциональной модели в рамках системного подхода как системного образования. В ее составе прежде всего интегративная функция, направленная на обеспечение публичности социальной жизнедеятельности в рамках субъективного фрактора цивилизационного развития. Это касается также познавательно-отражательных функций не только самой журналистики, но и других сфер социальной деятельности, освоения и преобразования действительности: духовно-теоретической (наука, искусство), духовно-практической (политика, управление, образование), практической (производство и др.). Существует острая необходимость более тесного взаимодействия между ними, чтобы активнее обогащать
} 
интеллектуальный потенциал общества и обновлять им содержание его инфрормационного потенциала.

Возрастает также роль функций структурных, коммуникативных, организационных в условиях дигитализации медиасистемы.

Ключевые слова. Публичность, функциональная целостность журналистики, картина текущей действительности, информационный потенциал общества, медиакартина мира.

Информация о статье. Дата поступления 21 декабря 2017 г.; дата принятия к печати 19 января 2017 г.; дата онлайн-размещения 31 января 2017 г.

\title{
JOURNALISM AS A FACTOR OF PUBLICITY: THE SYSTEMATIC ASPECT
}

\begin{abstract}
In the formation of a new stage of the civilization process, the contradiction between the need for social activities publicity and the media ability to meet this need is increasing. The systematic analysis of this issue shows the necessity to considerably update such an important characteristic of the media system as its functional, structural, communicative and organizational integrity.

Without diminishing the importance of further updating the traditional functions of journalism, the article describes the necessity to study its functional model as a system element in the framework of the systematic approach. This model, first of all, consists of the integrative function aimed at ensuring the social life publicity in the framework of the subjective factor of civilization development. This also applies to the cognitive-reflective function of not only journalism but other spheres of social life, this applies to learning about and transforming reality, i.e. mental and theoretical (sciences and arts), mental and practical (politics, management, education), practical (manufacturing, etc.). There is an urgent need for greater interaction between them, this will help to enrich the society intellectual potential and update its informative potential.

The importance of structural, communicative, organizational functions is also increasing in terms of the media system digitalisation.

Keywords. Publicity, the functional integrity of journalism, a picture of current reality, informational potential of the society, the media view of the world.

Article info. Received December 21, 2017; accepted January 19, 2017; available online January 31, 2017.
\end{abstract}

\section{I}

Магистральным направлением научных исследований на факультете журналистики МГУ имени М. В. Ломоносова, в Санкт-Петербургском университете и ряде других вузов стало изучение журналистики как системного объекта. В условиях смены цивилизационных эпох существенно меняется характер ее медийной целостности, в том числе функциональной, структурной, коммуникатив- ной, познавательно-отражательной и организационно-поведенческой.

На международной научной конференции 2016 г. «Информационный потенциал общества и ресурсы медиасистемы» деканом факультета журналистики МГУ профессором Е. Л. Вартановой была высказана мысль о насущной необходимости расширения информационных возможностей современного человека, всех субъектов социальной деятель- 
ности, обеспечения их активной роли в процессах освоения и преобразования мира на его новом цивилизационном пути'. Исследователи отмечают существенное возрастание необходимости журналистики для социальной системы, рассматривая ее как одну из важнейших общественных фуннций, которая направлена на обеспечение публичности социальной деятельности. К этому интегративному результату журналистика стремится, но не может пока его достичь в связи с новым цивилизационным этапом развития, требующим нового качества иноормационного взаимодействия в обществе, новых знаниевых, аксиологических и поведенческих ресурсов.

Журналистика - важнейший субъект инфоосрерь' ${ }^{2}$, тесно связанный с ноосферой, биосферой, антропосферой. Она рождена, чтобы отразить прежде всего информационный потенциал текущей жизнедеятельности общества, весь актуальный массив изменчивости явлений действительности и донести до сознания социальных общностей, участвующих в совместных и согла-

1 Журналистика в 2015 году. Информационный потенциал общества и ресурсы медиасистемы. Москва, 5-6 февраля 2016 г.

2 Инфосфера - сложная целостная система, вбирающая в себя медиасферу (медиасистему), а также другие сореры, основанные на информационном взаимодействии. Инфосорера - это совокупность информации, информационных объектов, информационных процессов, информационной инфраструктуры. Она включает в себя и участников межличностного и массового общения, осуществляющих сбор, обработку, хранение, распространение, производство и потребление информации, а также субъектов регулирования возникающих при этом отношений производства, использования, владения и распоряжения информацией. CM: URL: www.fundamentalresearch.ru / $\mathrm{ru} /$ article / view?id=31415. сованных процессах освоения и преобразования мира в рамках субъективного фрактора цивилизационного развития, чтобы связать эту изменчивость с устойчивыми тенденциями в этих явлениях, соотнести с особенным и всеобщим в них. Она призвана создавать в медийном пространстве такое информационное поле, такой информационный потенциал, который вбирает в себя интеллектуальный потенциал общества в процессе его непрерывного обновления и обогащения.

Основой публичности является медиакартина мира, которая образуется в сознании массовой аудитории, обогащая, обновляя информационный потенциал личности, различных социальных общностей, различных субъектов политики, экономики, науки, культуры и других видов социальной деятельности. Публичность немыслима без того, чтобы медиакартина мира, удовлетворяя информационные потребности аудитории, не вбирала бы в себя всю совокупность ресурсов интеллектуального потенциала общества, результаты его постоянного обогащения и обновления.

Важнейшим проявлением публичности является также массовое информационное взаимодействие, которое формируется в рождающемся и расширяющемся медийном пространстве. Прежде всего это взаимодействие между субъектами различных видов социальной деятельности, рожденной в системе общественного разделения труда субъектами, осуществляющими духовно-теоретическое, духовнопрактическое и практическое освоение и преобразование мира. Они формируют и потребляют знаниевые, аксиологические и поведенческие ресурсы экономики, политики, науки и культуры, которые активно 
влияют на информационный потенциал общества.

Расширение медийных возможностей личности, различных социальных общностей, по сути, - важнейший фактор на пути разрешения острого противоречия между общественными потребностями в публичности и возможностями их удовлетворения, которые предоставляет отечественная медиасистема [1].

Публичность в теории журналистики - это такое оптимальное состояние медийного взаимодействия между социальными субъектами, при котором в их сознании постоянно обновляется медиакартина мира, содержащая такую совокупность знаниевых, аксиологических, проективно-поведенческих информационных ресурсов, которые адекватны интеллектуальному потенциалу общества, непрерывно обновляющемуся в наполненной изменчивостью действительности, созвучны с реальными условиями жизни общества. Именно эти ресурсы помогают оптимизировать коллективную социальную деятельность по освоению и преобразованию действительности на пути цивилизационного развития в рамках субъективного фрактора общественного прогресса [2-4].

Факторами, ресурсами публичности, по нашему мнению, выступают интегративные образования, которыми располагает журналистика как системный объект, как медиасистема.

Сначала о функциональной целостности медиасистемы. Целый ряд авторов в своих исследованиях отмечали существование интегративной функции журналистики [5-7]. Функция выступает как отношение части к целому. В данном случае речь идет об отношении журналистики (части) к обществу (целому). Форма существования этой части есть фоорма су- ществования целого 3 . Общество не может существовать без журналистики, медиасистемы, обеспечивающих ему медийную публичность.

Прежде всего следует сказать о журналистике как о творческой деятельности, тесно связанной, наряду с наукой и искусством, с освоением мира. Всем явлениям действительности, всем условиям существования общества присущи свойства изменчивости и устойчивости ${ }^{4}$. Наука осуществляет теоретическое освоение мира, познавая законы и закономерности природы и общества, а искусство - художественное освоение освоение мира художественных ценностей [8].

Журналистика в значительно большей степени связана с освоением изменчивости в актуальных явлениях действительности. Познает она в пределах своей компетенции и влияние происходящих изменений на устойчивые тенденции тех или иных явлений, к которым они относятся, вызывая своими публикациями соответствующую познавательную активность у представителей науки

${ }^{3}$ URL: www.cih.ru/ab/b39.html.

4 Под изменчивостью мы понимаем смену свойств, состояний и отношений, принадлежащих материальным и идеальным системам. Устойчивость есть сохранение свойств, состояний и отношений этих систем. Движение включает в себя и изменчивость, и устойчивость одновременно. Наличие изменчивости в движении очевидно. Но и устойчивость обязательно включается в движение. Она «входит» в него даже в том смысле, что смена свойств, состояний и отношений (изменчивость) всегда присуща движению, т. е. сама смена (наличие изменчивости) является определенной устойчивостью. В реальном мире нет ни «чистой изменчивости», ни «чистой устойчивости», а есть движение, в котором изменчивость и устойчивость взаимодействуют и взаимопереплетаются. URL: http://www. greatphilosophy.ru/philgs-407-1.html. 
и искусства. Силами журналистики и ее авторского актива должна создаваться целостная картина текущей действительности [9]. Некоторые исследователи считают, что социальные сети и другие формы инфрормационной активности членов общества со временем заменят профессиональную журналистику. Но картина должна быть полной, объективной, адресуемая разным аудиториям. Она создается на основе регулирования информации в рамках редакционных служб. Учитывая высокую динамику жизнедеятельности общества, Г. В. Лазутина, А. А. Тертычный, М. Н. Ким и другие авторы характеризуют журналистику как форму оперативного освоения действительности [9-15].

\section{II}

Если говорить об организационной целостности массового информационного процесса, то между всеми социальным субъектами, в том числе наукой, искусством, политикой, экономикой, в том числе в сорерах рекламы, PR и др., ведущими массовую и корпоративную информационную деятельность, существуют организационные отношения координации с редакционными структурами СМИ.

Журналистике свойственны не только такие качества, как системность, функциональность, структурность, коммуникативность, отражательно-познавательная целостность, но и организованность. Все эти свойства - аспекты целостности журналистики, способствующие появлению интегративного результата ее функционирования - публичности [16-18].

Журналистика как социальная система должна располагать широкой совокупностью организационных отношений между всеми участниками массового информационного процесса, теми, кто создает интеллектуальные ресурсы, кто производит, распространяет и потребляет информацию на основе этих ресурсов. Чтобы обеспечить публичность различных видов социальной деятельности, взаимодействие между материальным и духовным производством, необходимо:

- сорормировать и непрерывно оптимизировать функциональную модель журналистики, ее функциональную целостность с учетом характера развития и преобразования условий жизни общества;

- оптимизировать и непрерывно совершенствовать структурную целостность журналистики, обеспечивая необходимый набор средств массовой информации, их типологическую и формативную обоснованность, кадровую и иную обеспеченность, способствующие реализации функций журналистики;

- создавать и совершенствовать оптимальные механизмы массового информационного взаимодействия в медийном пространстве между участниками производства, распространения и потребления массовых информационных ресурсов;

- обеспечивать, чтобы информационное поле журналистики в полной мере отражало в своем содержании интеллектуальный потенциал общества, реальные условия и фракторы, результаты его фрормирования и развития;

- обеспечивать создание на этой основе в сознании массовой аудитории реальной медиакартины мира с учетом интересов и потребностей общества, различных социальных общностей и структур, с учетом характера общественного разделения труда.

Для этого необходима широкая система организационных отноше- 
ний с оптимизированными процессами координации, сотрудничества, инициативы, дисциплины, ответственности между участниками массовой инфрормационной деятельности.

По отношению к обществу журналистика выполняет функцию, связанную с публичностью социальной деятельности. Публичность - это такое свойство, которое призвано обеспечить формирование коллективных информационных ресурсов в сознании всего общества, различных общественных групп, институтов, ресурсов знаниевых, аксиологических, поведенческих, создающих возможности социальным субъектам совместно осваивать и преобразовывать действительность в рамках субъективного фактора цивилизационного развития.

Журналистика обеспечивает такое регулирование массового инорормационного процесса, осуществляемого средствами массовой информации, которое в процессе изменчивости в актуальных общественных явлениях непрерывно оптимизирует публичную сореру в соответствии с развивающимися условиями жизни общества,

Функциональная целостность журналистики состоит в том, чтобы организовывать массовую информационную деятельность на основе принципов публичности, которые тесно связаны с ее критериями.

В массовом информационном процессе, обновляющем и осваивающем информационный потенциал общества, участвуют все творчески активные силы общества, составляющие ядро субъективного фрактора цивилизационного развития. Это огромная совокупность субъектов коллективной массовой информационной деятельности, участвующих в производстве массовой информации и ее потреблении, освоении:
- представители науки, осуществляющие теоретическое освоение действительности;

- представители искусства, ведущие художественное освоение мира;

- представители образования, распространяющие научные знания, художественные и иные ценности в обществе;

- представители сореры управления, властных и правовых структур, обеспечивающих публичность политики, права, структур законодательной, исполнительной, судебной властей, других элементов системы организации и управления;

- представители гражданского общества, различных партий, движений, профессиональных, молодежных, других общественных организаций, участники производственно-практической деятельности, выражающие общественное мнение и настроения, выступающие с предложениями и критикой;

- представители рекламной и PR-деятельности, обеспечивающие публичность структур различных видов социальной деятельности и управления;

- субъекты информационной политики в сферах законодательной, исполнительной и судебной властей, участвующие в ее формировании и реализации [19].

\section{III}

Коммуникативное взаимодействие осуществляет не только внутренняя структура журналистики, но и образуемое на ее основе медиапространство, которое охватывает также среду этой структуры, медиасистемы в целом.

В российской медиасистеме дигитализация заметно расширяет границы публичности, вовлекая в массовый информационный про- 
цесс значительные социальные общности, но, тем не менее, целый ряд важных интегративных качеств медийной сферы пока не реализуется в должной мере. В условиях становления информационного общества публичность социальной деятельности обретает важные интегративные качества и свойства. Вместе с тем в российском обществе многие проблемы публичности еще не решены, и дигитализации в их решении принадлежит важная роль. Пока существует острое противоречие между интеллектуальным потенциалом общества и тем, как он используется в процессе освоения и преобразования действительности [20-22].

Значительная часть продуктивных знаний, аксиологических, поведенческих информационных ресурсов не становится содержанием медиакартины мира в сознании личности, различных социальных общностей, в сознании массовой аудитории. И одна из причин - уровень развития технической подсистемы медиасферы, вооруженности новыми технологиями различных социальных субъектов.

В этой связи, как отмечает Е. Л. Вартанова, многие политические и экономические реалии, отраженные в СМИ, не соответствуют ожиданиям общества, его различных институтов. По ее мнению, в условиях технологической революции, становления информационного общества все острее становится необходимость в раскрытии информационных возможностей современного человека, широкого круга субъектов различных видов социальной деятельности [23].

Задача состоит не только в том, чтобы расширить объем информационных ресурсов личности, различных социальных общностей, которые действуют в новых условиях преобразования действительности.
Необходимо через массовый информационный процесс расширить возможность личности, различных социальных общностей и структур активизировать свое участие в процессах освоения и преобразования мира на основе интеллектуализации их социальной деятельности как деятельности коллективной, сознательной, организованной в рамках субъективного фактора цивилизационного развития.

Важно, чтобы информационные потоки базировались на инновационной основе, на интеллектуальном потенциале общества, на новейших достижениях в материальном и духовном производстве, которые рождает современный этап социального прогресса. Использование системного, синергетического подходов позволяет в условиях дигитализации существенно актуализировать многие интегративные результаты массовой информационной деятельности. Речь прежде всего идет о функциональной целостности медиасистемы, которая вбирает в себя всю совокупность ее функций и оптимизирует ее с учетом реальных условий функционирования медиасферы, в том числе ее коммуникативных функций. Новые возможности социальной среды, созданные научно-техническим прогрессом, дигитализацией СМИ, вызывают необходимость пересматривать их функциональные модели для использования в практической деятельности новых возможностей публичности. На этой основе требуется дальнейшее наращивание функционального потенциала медиасистемы.

Структурная целостность журналистики в процессе дигитализации также претерпевает серьезную модернизацию. Идет существенная перестройка типологической структуры медиа, механизмов их связи с медиасредой, способов связи меж- 
ду компонентами, что способствует более полной реализации системных закономерностей и функций. Технологическая подсистема СМИ, испытывающая под воздействием дигитализации существенные перемены, должна оказывать на структурную трансформацию СМИ более активное влияние. На базе цифровых технологий преобразуется коммуникативная целостность медиасистемы. Информационное взаимодействие между социальными субъектами на цифровой технологической основе значительно расширяет границы медиапространства. Растет взаимодействие:

- между теорией и практикой, наукой и производством, политикой и экономикой;

- между сознанием личности, различных социальных общностей и общественным сознанием;

- между теоретическим, духовно-практическим и практическим сознанием;

- между идеологией и общественной психологией;

- между различными состояниями сознания: мировоззрением, общественным мнением, общественным настроением и др.

- между различными формами общественного сознания: правового, политического, экономического и др.

Дигитализация несет расширение и интенсификацию информационных взаимодействий между социальными субъектами, что существенно влияет на познавательно-отражательную целостность медиасистемы. Расширяется круг производителей информации, создающий возможности более адекватного отражения интеллектуального потенциала общества, результатов духовного и материального производства в информационном потенциале медиасистемы. Растут возможности более полного отражения этого потенциала в медиакартине мира, обогащающей сознание массовой аудитории. В этих условиях обеспечивается адекватность процесса обновления, обогащения информационного потенциала общества процессу обогащения, обновления его интеллектуального потенциала. Инновационные результаты, достигаемые в системе общественного разделения труда, становятся доступными каждому социальному субъекту.

\section{IV}

В коммуникационном процессе особое место занимают коммуникации по поводу экономических событий, интересов, самой сущности экономической науки и практики - то, что мы называем экономическими массовыми коммуникациями (ЭМК) [24]. В свою очередь, каждая из составляющих ЭМК (PR, реклама, экономическая журналистика [25; 26]), несомненно, представляет огромный интерес для медиаисследователей, особенно в России, где за последние годы все три компонента ЭМК развивались галопирующими темпами, методами проб и ошибок, внедрения зарубежных коммуникативных форм и методов, не всегда бесспорных. Современный этап генезиса экономических коммуникаций (да и коммуникаций во всех других сорерах человеческой жизнедеятельности) носит конвергентный характер, т. е. то, что совсем недавно считалось неэтичным, «неправильным» с точки зрения нормативной теории журналистики, сегодня институционализируется, приобретает характер обычной повседневной практики, изучается в университетах как «законные» коммуникативные технологии. Примеров - масса.

Так, конвергенция рекламы и журналистики проявляется в так назы- 
ваемой нативной рекламе, которая по сути является рекламой скрытой, запрещенной в Федеральном законе «O рекламе»: Не допускаются использование в радио-, теле-, видео-, аудио- и кинопродукции или в другой продукции и распространение скрытой рекламы, т. е. рекламы, которая оказывает не осознаваемое потребителями рекламы воздействие на их сознание, в том числе такое воздействие путем использования специальных видеовставок (двойной звукозаписи) и иными способами о чем «выгодно» забыть активным участникам коммуникативного процесса. Материалы журналистские и PR сегодня вообще практически неразличимы, что в полнейшей мере со всей очевидностью проявляется в коммуникации политической (политтехнологии, выстраивание образовсимулякров и т. д.).

Та же история во многом повторяется и для экономических коммуникаций. Реклама, PR и журналистика все более сближаются, сливаются. Это происходит в первую очередь вследствие экономических факторов - власть крупного монополизированного капитала, транснациональных и национальных корпораций, обладающих достаточными фринансовыми активами, обращается во власть информационную, а средства массовой информации, действующие на мадиарынке, собственные бизнесмодели строят на коммерциализации контента, причем «заказчиками» такого контента являются аккумулирующие огромные (и не обязательно огромные) фринансовые средства. Пока трудно прогнозировать, какими будут массовые коммуникации при сохранении этого тренда букваль-

5 О рекламе : фредер. закон РФ от 13 марта 2006 г. № 38-Ф3 // СПС «КонсультантПлюс». но через пару лет, однако, остается надеяться, что журналистика, как общественный, социальный институт, сохранит свои позиции, отстоит принципы и переосмыслит функции, ей присущие на протяжении многих лет, и выделит новые, оставаясь при этом именно журналистикой в многолетнем понимании.

Переосмысление функций журналистики и разграничение ее в этом смысле с PR и рекламой возможно в любой из сорер человеческой деятельности, примером могут быть размышления о функциях экономической журналистики. В наших рассуждениях оттолкнемся от нескольких постулатов. Во-первых, функции экономической журналистики можно разделить на две большие группы: функции (роли, предназначение журналистики), присущие журналистике, какую бы из сорер социальной жизни она, как специфическая социальная практика, ни освещала. Существует масса теоретических исследований отечественных и зарубежных авторов, дискутирующих об этих общих функциях. Каковы бы не были результаты таких исследований, общие функции журналистики так же применимы к журналистике экономической, как и, например, политической, социальной и т. д. Кроме этих, общих функций журналистики, экономической журналистике должны быть присущи функции особые, специальные, специфические, связанные с объектом - экономикой.

Во-вторых, набор функций экономической журналистики во многом зависит от конкретно-исторического этапа, в котором пребывает общество. отдельные функции выходят на первый план в определенные периоды, могут актуализироваться в связи с конкретными экономическими событиями, могут, казалось бы, вовсе «исчезать» из информа- 
ционного поля, чтобы, может быть «возродиться» вновь в условиях аналогичных. Функции актуализируются вслед за потребностями общества, элит либо других акторов исторического процесса, а значит, целей, которые эти акторы ставят перед журналистикой и медиа. При этом не стоит забывать, что медиасистема, по всей видимости, является частично целенаправленной: она лишь частично, в той или иной мере, построена "сверху», действует по воле небольшой группы, обладающей политической или финансовой властью. В этой своей (организованной) части цели активных коммуникаторов определяют фрункции и структуру медиасистемы. В определенной, более или менее значительной части, медиасистема является самоорганизующейся, т. е. цели и функции тех или иных медиа определяет не немногочисленная группа обладающих институционализированной либо финансовой властью, а небольшие комьюнити, частные лица, организации и др., цели которых не совпадают с целями монополизированных элит. Тогда не совпадают и функции. При этом необходимо помнить, что векторной целью медиасистема (в соответствии с теорией систем) несомненно обладает, однако цель эта не является простой суммой целей и фрункций отдельных компонентов медиасистемы. Медиасистема система сложная, в которой рождается новое качество, не всегда очевидны результаты функционирования нашей медиасистемы, тем более, что они проявляются во всей социальной системе, и в какой мере изменения социальной системы являются следствием функционирования медиасистемы, а в какой - результатом воздействия других (политических, культурных, демографических и др.) фракторов, - неочевидно и пока не поддается количественному измерению.

Из второго положения можно сделать вывод о третьем: участники коммуникационного процесса могут по-разному понимать функции журналистики. Если к таким участникам относить власть, бизнес и общество, то, очевидно, интересы каждой из групп не равны между собой, могут противоречить друг другу, во всяком случае необходимо искать и находить компромиссы, чему, в том числе, способствуют медиа, как каналы коммуникации, и журналисты, как профессиональные коммуникаторы. Очевидно, эти группы участников коммуникации будут понимать цели СМИ по-разному, соответственно, придавать журналистике разные функции. Именно поэтому сегодня чрезвычайно важна роль непредвзятых, объективных, не служащих интересам, к примеру, бизнеса, исследователей журналистики и теории журналистики, разделяющей эту социальную практику с PRдеятельностью и рекламой.

В 1970-1980-х гг. советские экономисты-публицисты поставили в повестку дня СМИ идею о пороках плановой экономики, эта идея попала на благодатную почву общественных потребностей и, видимо, чаяний тогдашних элит. 1980-е - время расцвета советской публицистики, но экономическая публицистика тогда очень серьезно и со знанием деле поставила в повестку дня пороки именно плановой экономики. Общественное мнение оказалось подготовленным к известным изменениям в нашей стране, в частности, смене экономической парадигмы и смене плановой экономики на рыночную.

Изменения, произошедшие за последние 30 лет в России, не могли не затронуть сореру массовых коммуникаций, в том числе журналистику. 
В настоящее время уже можно сделать некоторые выводы о фрункционировании журналистики, о тех функциях, которые актуализировались или актуализируются по мере возникновения общественных потребностей в них. Кроме заявленных постулатов, за последние годы появился и стал во многом определяющим для функций СМИ еще один фактор, а именно, фррагментация аудитории (как этот фрактор определяет теория журналистики) или сегментирование медиарынка (этот же фрактор с точки зрения медиамаркетинга). Появилось множество новых типов СМИ в соответствии с интересами, стилем жизни, и т. д. Если говорить об экономической журналистике, она так же трансформировалась: можно говорить об экономической журналистике в массовых СМИ, и экономической журналистике в деловых медиа.

Общими функциями журналистики остаются образовательная и воспитательная. В связи с этим экономическая журналистика должна выполнять функцию популяризации экономической науки, экономических практик, разъяснять массовой аудитории основные экономические категории, законы экономической науки, воспитывать «экономического человека». Экономическая журналистика призвана определять экономическое поведение аудитории, внедрять экономическую культуру [27]. Эта функция характерна, прежде всего, для массовых СМИ. Наука экономика, по сравнению с естественными науками, кажется слишком скучной, в ней невозможны эффректные эксперименты, кажущиеся фантастическими результаты. Именно поэтому в научной журналистике экономика - практически невозможный объект рассуждений и обсуждений в научно-популярных передачах на телевидении («Черные дыры, белые пятна», «Истории из будущего» и др.). От экономической журналистики массовая аудитория ждет прогнозов курсов валют и инфляции, аналитики, помогающей принимать решения в каждодневной жизни: на какой стадии экономического цикла мы находимся, будет ли работа, размер зарплат и пенсий, сохранять или тратить деньги, если сохранять, то каким образом, какие стратегии выбрать в образовании детей и т. д. - вот вопросы, на которые необходимо получить ответы массовой аудитории. Пожалуй, информационная и образовательная функции остаются основными для массовых СМИ.

Интересно, что разные участники коммуникационного процесса в публичном пространстве по-разному оценивают роль экономической журналистики (в соответствии с одним из наших постулатов). Так, представители крупных банков считают, что нежелание индивидов использовать кредитные карты, безналичный расчет по дебетовым или кредитным картам - результат фринансовой безграмотности. Поэтому одной из функций журналистики является повышение финансовой грамотности (с этим трудно спорить). В то же время в журналистских материалах, посвященных этой теме, как правило, ничего не говорится об опасностях такого поведения. Здесь медиа выступают как фрильтры инфрормации, а вместо журналистики (один из принципов которой - распространение непредвзятой инфрормации) мы имеем дело с PR и рекламой. Об опасностях бездумного поведения - другие тексты.

Деловые СМИ, наряду с информационной, выполняют функцию аналитическую и организационную. Аудитория деловых СМИ достаточ- 
но образована и часто принимает решения совсем на другом уровне. Деловая информация предназначена выполнять инфраструктурную роль в рыночной экономике [28], предоставляя объективную, релевантную информацию для людей, принимающих решения.

Функции журналистики как деятельности и медиа, как каналов для распространения результатов этой деятельности, коммуникативных актов в публичном пространстве, всегда останутся предметом дискуссий и ждут дальнейших исследований.

\section{выводы}

Журналистика как сложное образование обладает множеством системных свойств, которые характеризуют ее как интеллектуальную систему. Прежде всего мы видим два интегративных результата.

Журналистика отражает повседневную содержательность актуальных общественных явлений, в основе которых лежит изменчивость в этих явлениях. Она соединяет эту изменчивость с устойчивыми тенденциями общественного развития, выполняя важные познавательно-аксиологические и проективно-поведенческие функции. В информационном потенциале общества журналистика составляет ту ее часть, которая обеспечивает непрерывное отражение текущей действительности, удовлетворение информационных потребностей различных социальных субъектов - личности, группы, организации, создавая в их сознании медиакартину мира как постоянно изменяющуюся действительность, объединяющую изменчивые и устойчивые тенденции.

Рассматривая журналистику в ключе творческой деятельности, мы можем ее отнести к духовному производству. Если наука осваивает всеобщее в явлениях, а искусство особенное, типическое, то предмет журналистики - изменчивость, непрерывно, каждодневно преобразующая эти явления. Знаниевые, аксиологические и поведенческие ресурсы, создаваемые ею, предусматривают соответствующую корректировку в инорормационном потенциале общества, обеспечивая соответствие этого потенциала непрерывному развитию условий жизни общества.

Журналистика также представляет собой редакционную систему, систему организации массового инфрормационного процесса. Как организатор она располагает совокупностью функций в рамках различных социальных пространств, связанных с производством, распространением и потреблением массовой информации. Каждое медиапространство может быть оптимальным как структурное образование, если каждый социальный субъект отдельного медиапространства может непрерывно обогащать свой информационный потенциал и продуктивно использовать информационные ресурсы этого потенциала для сотрудничества с другими участниками взаимодействия в совместном освоении и преобразовании мира.

Говоря об организованности медиапространства, мы имеем в виду:

- достаточно ли информационный потенциал общества, обогащенный и обновленный повседневностью, соответствует достижениям интеллектуального потенциала общества - тем знаниевым, аксиологическим и поведенческим ресурсам, которые непрерывно возникают в сорерах духовно-теоретической, духовно-практической и практической деятельности;

- достаточно ли полно отражается информационный потенциал об- 
щества, обновленный журналистикой совместно с другими сферами деятельности, в медиакартине мира, которую фрормируют и обновляют в своем сознании различные социальные общности, действующие во множестве различных социальных пространств, объединенных единым социальным пространством.

Современный цивилизационный этап развития общества стремительно повышает ответственность теории журналистики. В ее задачу входит четко определить характер тех интегративных качеств и свойств, которые должны быть присущи современной журналистской деятельности.

Массовое общение, общественный диалог фрормируют информационные отношения между всеми социальными субъектами. Уровень развития этих информационных отношений в идеале будет таким, когда каждый социальный субъект становится публичным социальным субъектом. Это значит, что он:

- открыт для других социальных субъектов;
- может участвовать в массовой информационной деятельности как источник информации, как ее создатель и распространитель;

- может в полной мере удовлетворять свои информационные потребности, осваивая создаваемый информационный потенциал общества.

Чтобы быть публичными, массовые информационные отношения должны иметь в результате массового общения между социальными субъектами адекватное отражение условий жизни общества на уровне:

- результатов научной деятельности;

- результатов художественного освоения мира;

- результатов художественнопублицистического, журналистского освоения;

- результатов духовно-практического освоения в сорерах управления, образования и воспитания;

- результатов практического освоения, выраженного в социальном опыте, в общественном мнении, социальном капитале и др.

\section{СПИСОК ИСПОЛЬЗОВАННОЙ ЛИТЕРАТУРЫ}

1. Вартанова Е. Л. О необходимости модернизации концепций журналистики и СМИ / Е. Л. Вартанова / / Вестник Московского университета. Сер. 10, Журналистика. - 2012. № $1 .-$ C. 7-26.

2. Арендт X. Vita active, или о деятельности жизни / X. Арендт. - СПб. : Алетейя, 2000. $-437 \mathrm{c}$.

3. Habermas J. The Structural Transformation of the Public Sphere: An Inquiry into a category of Bourgeois Society / J. Habermas. - Cambridge : MIT Press, 1962. - 301 p.

4. Luhmann N. Die Realitat der Massenmtdien / Niklas Luhmann. - Wiesbaden : Westdeutscher Verlag, 2004. - $256 \mathrm{~s}$.

5. Корконосенко С. Г. Теория журналистики: моделирование и применение / С. Г. Корконосенко. - М. : Логос, 2010. - 242 с.

6. Прохоров Е. П. Введение в теорию журналистики : учебник / Е. П. Прохоров. 8-е изд., испр. - М. : Аспект Пресс, 2011. - 351 с.

7. Шкондин М. В. Функциональная целостность медиасистемы / М. В. Шкондин // Известия Иркутской государственной экономической академии. - 2014. - № 2 (94). C. 144-149.

8. Степин В. С. Научная картина мира в культуре техногенной цивилизации / В. С. Степин, Л. Ф. Кузнецова. - М. : Проспект, 1994. - 262 с.

9. Шкондин М. В. Система средств массовой информации как фактор общественного диалога / М. В. Шкондин. - М. : Пульс, 2002. - 120 с.

10. Ким М. Н. Основы творческой деятельности журналиста / М. Н. Ким. - СПб. : Питер, 2011. - 400 c. 
11. Лазутина Г. В. Журналистика в жизни общества - пером теоретика и практика / Г. В. Лазутина. - М. : Фак. журналистики МГУ, 2016. - 252 с.

12. Олешко В. Ф. Журналистика как творчество / В. Ф. Олешко. - М. : РИП-Холдинг, 2005. -222 c.

13. Мансурова В. Д. Журналистская картина мира как фактор социальной детерминации / В. Д. Мансурова. - Барнаул : Изд-во Алт. гос. ун-та, 2002. - 237 с.

14. Мисонжников Б. Я. Отражение действительности в тексте / Б. Я. Мисонжников // Основы творческой деятельности журналиста / под ред. С. Г. Корконосенко. - СПб. : Знание, 2000. - 272 с.

15. Тертычный А. А. О понятийной основе современной теории журналистики / А. А. Тертычный // Научные ведомости Белгородского государственного университета. Сер. : Гуманитарные науки. - 2014. - № 6 (161). - С. 290-295.

16. Вартанова Е. Л. Постсоветские трансформации российских СМИ и журналистики / Е. Л. Вартанова. - М. : МедиаМир, 2013. - 280 с.

17. Смирнова О. В. Стратегии печатных медиа в эпоху цифровых технологий / О. В. Смирнова / / Вестник Московского университета. Сер. 10, Журналистика. - 2013. № 6. - С. 25-37.

18. Свитич Л. Г. Современная периодика: поле понятий и терминов / Л. Г. Свитич // Вестник Московского университета. Сер. 10, Журналистика. - 2013. - № 6. - С. 7-26.

19. Шкондин М. В. Медиасфрера как публичная система: аспекты целостности и инновационности / М. В. Шкондин / / Реклама и связи с общественностью: традиции и инновации. - Ростов н/Д. : Рост. гос. ун-т путей сообщения, 2016. - С. 4-13.

20. Дунас Д. Проблема изучения журналистики в поле массовой коммуникации: взгляд зарубежных исследователей / Д. Дунас / / Меди@льманах. - 2013. — № 1. - С. 6-15.

21. Свитич Л. Г. Феномен журнализма / Л. Г. Свитич. - М. : Фак. журналистики МГУ, 2000. $-252 \mathrm{c}$.

22. Смеюха В. В. Вопросы медиалогии / В. В. Смеюха. - Ростов н/Д. : Рост. гос. ун-т путей сообщения, 2013. - 324 с.

23. Вартанова Е. Л. Факторы модификации российских СМИ и проблемы социальной ответственности [Электронный ресурс] / Е. Л. Вартанова // Медиаскоп. - 2009. № 1. - Режим доступа: www/mediascope.ru/node/261.

24. Демина И. Н. Экономическая коммуникация. Обоснование термина / И. Н. Демина // Известия Иркутской государственной экономической академии. - 2012. № 1 (81). - С. 162-166.

25. Демина И. Н. О сущности экономической массовой коммуникации / И. Н. Демина // Известия Иркутской государственной экономической академии. - 2012. № 3 (83). - С. 175-179.

26. Демина И. Н. Методологические подходы к исследованиям роли экономической массовой коммуникации в формировании экономического поведения [Электронный ресурс] / И. Н. Демина // Медиаскоп. - 2012. - № 4. - Режим доступа: http: / / www. mediascope.ru/node/1222.

27. Демина И. Н. Сущность экономической журналистики / И. Н. Демина / / Известия Иркутской государственной экономической академии. - 2011. - № 1 (75). - С. 217-221.

28. Демина И. Н. Экономическая массовая коммуникация в производственной инфраструктуре / И. Н. Демина // Медиаальманах. - 2013. - № 1. - С. 26-35.

\section{REFERENCES}

1. Vartanova E. L. On the need to update the concepts of journalism and media. Vestnik Moskovskogo universiteta. Seriya 1, Zhurnalistika = Moscow University Bulletin. Journalism, 2012, no. 1, pp. 7-26. (In Russian).

2. Arendt H. Vita active, ili o deyatel'nosti zhizni [Vita active, or about active life]. Saint Petersburg, Aleteiya Publ., 2000. 437 p.

3. Habermas J. The Structural Transformation of the Public Sphere: An Inquiry into a category of Bourgeois Society. Cambridge, MIT Press, 1962. 301 p.

4. Luhmann Niklas. Die Realitat der Massenmtdien. Wiesbaden, Westdeutscher Verlag, 2004. $256 \mathrm{~s}$. 
5. Korkonosenko S. G. Teoriya zhurnalistika: modelirovanie i primenenie [The Theory of Journalism: Modeling and Application]. Moscow, Logos Publ., 2010. 242 p.

6. Prokhorov E. P. Vvedenie $v$ teoriyu zhurnalistiki [Introduction to the Theory of Journalism]. $8^{\text {th }}$ ed. Moscow, Aspekt Press Publ., $2011.351 \mathrm{p}$.

7. Shkondin M. V. Functional integrity of the media system. Izvestiya Irkutskoi gosudarstvennoi ekonomicheskoi akademii = Izvestiya of Irkutsk State Economics Academy, 2014, no. 2 (94), pp. 144-149. (In Russian).

8. Stepin V. S., Kuznetsova. L. F. Nauchnaya kartina mira v kul'ture tekhnogennoi tsivilizatsii [The Scientific Picture of the World in the Culture of Technological Civilization]. Moscow, Prospekt Publ., 1994. 262 p.

9. Shkondin M. V. Sistema sredstv massovoi informatsii kak faktor obshchestvennogo dialoga [The System of Mass Media as a Factor of Social Dialogue]. Moscow, Pul's Publ., 2002. 120 p.

10. Kim M. N. Osnovy tvorcheskoi deyatel' nosti zhurnalista [Fundamentals of Creative Activity of Journalists]. Saint Petersburg, Piter Publ., 2011.400 p.

11. Lazutina G. V. Zhurnalistika v zhizni obshchestva - perom teoretika i praktika [Journalism in the Life of Society from the Viewpoint of Theory and Practice]. Faculty of Journalism, Lomonosov Moscow State University Publ., 2016. 252 p.

12. Oleshko V. F. Zhurnalistika kak tvorchestvo [Journalism as an Art]. Moscow, RIP-Kholding Publ., 2005. 222 p.

13. Mansurova V. D. Zhurnalistskaya kartina mira kak faktor sotsial'noi determinatsii [Journalistic Picture of the World as a Factor of Social Determination]. Barnaul, Altai State University Publ., 2002. 237 p.

14. Misonzhnikov B. Ya. Interpretation of reality in texts. In Korkonosenko S. G. (ed.). Osnovy tvorcheskoi deyatel'nosti zhurnalista [Fundamentals of Creative Activity of Journalists]. Saint Petersburg, Znanie Publ., 2000. 272 p. (In Russian).

15. Tertychnyi A. A. On conceptual principles of modern theory of journalism. Nauchnye vedomosti Belgorodskogo gosudarstvennogo universiteta. Seriya Gumanitarnye nauki $=$ Belgorod State University Scientific Bulletin Humanities Philology. Journalism. Pedagogy. Psychology, 2014, no. 6 (161), pp. 290-295. (In Russian).

16. Vartanova E. L. Postsovetskie transformatsii rossiiskikh SMl i zhurnalistiki [The postSoviet Transformation of the Russian Media and Journalism]. Moscow, MediaMir Publ., 2013. $278 \mathrm{p}$.

17. Smirnova O. V. Print media strategies in the age of digital technologies. Vestnik Moskovskogo universiteta. Seriya 10. Zhurnalistika = Moscow University Bulletin. Journalism, 2013, no. 6, pp. 25-37. (In Russian).

18. Svitich L. G. Modern Press: A field of notion and terms. Vestnik Moskovskogo universiteta. Seriya 10, Zhurnalistika = Moscow University Bulletin. Journalism, 2013, no. 6, pp. 7-26. (In Russian).

19. Shkondin M. V. The Media Environment as a Public System: Integrity and Innovation Aspects. Reklama i svyazi s obshchestvennost'yu: traditsii i innovatsii. Chast' 1 [Advertising and Public Relations: Tradition and Innovation]. Rostov-on-Don, Rostov State Transport University Publ., 2016, pp. 4-13. (In Russian).

20. Dunas D. Studying Journalism in the field of mass communication: Foreign researchers' view of the issue. Medi@Imanah Journal, 2013, no. 1, pp. 6-15. (In Russian).

21. Svitich L. G. Fenomen zhurnalizma [The Phenomenon of Journalism]. Moscow State University Publ., 2000. 252 p.

22. Smeyukha V. V. Voprosy medialogii [Issues of Medialogia]. Rostov-on-Don, Rostov State Transport University Publ., 2013. 324 p.

23. Vartanova E. L. Modernization factors of mass media and problem of social responsibility. Mediaskop, 2009, no. 1. Available at: www/mediascope.ru/node/261. (In Russian).

24. Demina I. N. Economic communication. Substantiation of term. Izvestiya Irkutskoi gosudarstvennoi ekonomicheskoi akademii = Bulletin of Irkutsk State Economics Academy, 2012, no. 1 (81), pp. 162-166. (In Russian).

25. Demina I. N. About essence of economic mass communication. Izvestiya Irkutskoi gosudarstvennoi ekonomicheskoi akademii = Izvestiya of Irkutsk State Economics Academy, 2012, no. 3 (83), pp. 175-179. (In Russian). 
26. Demina I. N. Methodological approaches to investigating the role of economic mass communications in formation of economic behaviour. Mediascop, 2012, no. 4. Available at: http:// www.mediascope.ru/node/1222. (In Russian).

27. Demina I. N. Essence of economic journalism. Izvestiya Irkutskoi gosudarstvennoi ekonomicheskoi akademii = Izvestiya of Irkutsk State Economics Academy, 2011, no. 1 (75), pp. 217-221. (In Russian).

28. Demina I. N. Economic Mass Communication in Production Infrastructure. Medi@Imanah Journal, 2013, no. 1, pp. 26-35. (In Russian).

\section{БИБЛИОГРАФИЧЕСКОЕ ОПИСАНИЕ СТАТЬИ}

Демина И. Н. Журналистика как фактор публичности: системные аспекты / И. Н. Демина, М. В. Шкондин / / Вопросы теории и практики журналистики. - 2017. - Т. 6, № 1. C. 14-29. - DOI: 10.17150/2308-6203.2017.6(1).14-29.

\section{REFERENCE TO ARTICLE}

Demina I. N., Shkondin M. V. Journalism as a Factor of Publicity: the Systematic Aspect. Voprosy teorii i praktiki zhurnalistiki = Theoretical and Practical Issues of Journalism, 2017, vol. 6, no. 1, pp. 14-29. DOI: 10.17150/2308-6203.2017.6(1).14-29. (In Russian). 